\title{
Organization of Production Systems with the Use of Digital Factory Tools
}

\author{
Dariusz Plinta* \\ Department of Industrial Engineering, University of Bielsko-Biala, Poland
}

Submission: June 20, 2017; Published: August 14, 2017

*Corresponding author: Dariusz Plinta, Production Engineering Department, University of Bielsko-Biala, Willowa 2, 43-309, Bielsko-Biala, Poland, Email: dplinta@ath.bielsko.pl

Abstract

Contemporary production enterprises operate in conditions, which demand continuous improvement of their activity. Therefore, organization and optimization of the realized production processes becomes a more essential problem. That is why it is necessary to use different modern methods and tools aiding production. The digital factory tools can be an effective basis for improving of production systems. Thanks to computer simulation of virtual production systems it is possible to check if the modeled future solution (improvement of the present production system) fulfils the defined requirements. However, it make possible to find the best improvement variant of the analyzed system in a quicker way.

\section{Introduction}

Recently, the digitalization of production enterprises is more popular in designing of production systems. A lot of companies accomplish this by the implementation of integral software packages. The digitizing of production systems is almost connected with the entire production process, from the design a new product, through supply, manufacturing and sale. The use of computer tools in manufacturing does not only contain the planning and recording of realized works, but also the design of departments, production lines, workplaces, the analysis of executed works from point of view of automation, the control of NC machines and robots, the simulation of processes, and production management.

The evolution of production systems mainly follows the development of innovative technology and its direct environment, like machines, devices, methods and tools aiding the work related to preparing technical documentation, including description of product models, processes and production resources. This can be achieved by introducing shorter production cycles, new products and manufacturing processes development, minimization of the supplies level, more efficient logistics, and the usage of effective and in novative ideas of production realization, like Lean Production, JIT (Just in Time), Total Quality Management, and particularly,
Digital Factory Technologies [1,2]. These methods allow for effective production management by constant improvements of work organization and usage of different modern tools by engineers and managers [3]. Thanks to this, integration of tasks and functions takes place in two areas of a company, i.e. in management and production realization.

\section{Digital Factory}

The Digital Factory concept bases on the Virtual Reality, which is a computer technology supported by hardware and software [4]. It enables to create virtual models of real objects and use them for visualization of products and manufacturing processes. Digital Factory is appropriate mainly as a support for manufacturing of highly sophisticated products, their planning, simulation and optimization. The main current application area is automotive industry, mechanical engineering industry, aerospace and ship building industry, as well as electronics and consumer goods industries.

It is possible to use Virtual Reality technologies to design 3D spatial models and 3D modeling and examination of properties of real objects. On the other hand, Virtual Reality enables to create "real" spatial environment, in which we can conduct the required activities. The possibilities for Virtual Reality technologies development are tremendous and they are 
still growing. Virtual Reality can be used for different kinds of analysis connected with product development, designing production processes, workplaces, production systems, etc. The use of Virtual Reality for design and optimization of production processes and systems is often called Digital Factory application $[5,6]$.

Digital Factory can be described as a virtual picture of a real production. It represents the environment integrated by computer and information technologies, in which reality is replaced by virtual computer models (Figure 1). Such virtual solutions enable to verify all collisions and critical situations before real implementation of the proposed solutions. Digital Factory can support planning, organization and optimization of complex production, and simultaneously creates right conditions for team work, providing quick feedback among designers, technologists, production systems designers and planners. The most important advantage of Digital Factory is the possibility to realize process planning and product development using common data. It gives a possibility to optimize products, processes and production systems even by the development phase with the use of $3 \mathrm{D}$ visualization and modeling techniques.

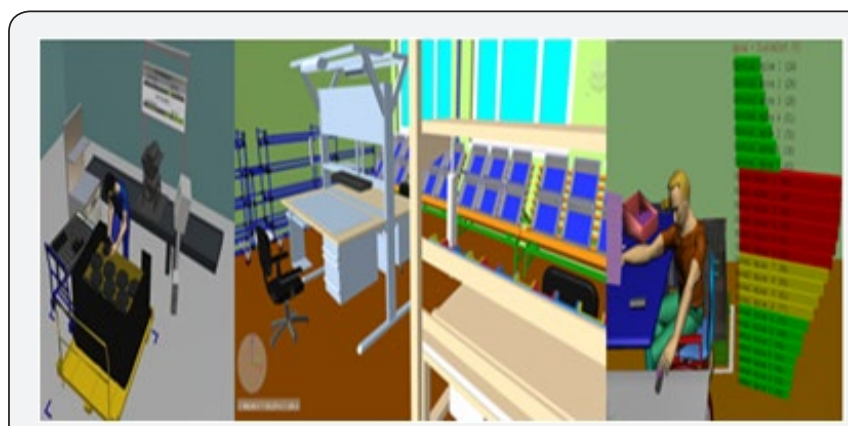

Figure 1: Example of virtual models of production workplaces.

\section{Conclusion}

New information technologies, which are mentioned above, all together integrate the whole production process, from product design to its manufacturing. Generally, such integrated systems are connected with the six following areas:

a. Product design systems (modeling and simulation of products),

b. Process planning systems (process and production plans, assembly plans, work standardization, value analysis, cost analysis, etc.), c. Production process design and validation systems (NC systems, production process simulation, assembly, inspection, maintenance, etc.),

d. production engineering systems (complex production scenarios, layout design, time analysis, ergonomics analysis, designing and analyzing manufacturing and assembly systems, load on machines and workers, etc.),

e. production planning and control systems (ERP planning systems),

f. Automation and process control systems (programmes for controlling and monitoring in automated production systems, PLC systems, industrial robots, etc.).

The future outlook shows that digital factory can bring benefits to next generations of products. All types of processes and products will be modified and developed in the future, and these activities should be aided by new information tech nologies to achieve a competitive advantage. Current research requires huge investment. Governments support innovative research and new strategies, like the concept Industry 4.0. Our industry requires Digital Factory solutions, but unfortunately it is still only a concept, which should be popularized. The common intention of different universities, like for Example University of Bielsko-Biala, is to develop a concept of a fully integrated system for factories. Such a solution will also support the education of future designers, designers of manufacturing systems, technologists and managers.

\section{References}

1. Gregor M, Medvecký Š, Mičieta B, Matuszek J, Hrceková A (2009) Digital Factory. J Automation Mobile Rbts Intlgnt Stms 3(3): 123-132.

2. Krajčovič M, Bulej V, Sapietova A, Kuric I (2013) Intelligent manufacturing systems in concept of digital factory. Communications 15(2): 77-87.

3. Plinta D, Więcek D (2012) Production systems design. Scientific Publishing House of the Academy of Humanities, Bielsko-Biala. Poland.

4. Haas W (2004) AK-DigitaleFabrik. Bericht Roadmap, Ingolstadt, Germany.

5. Bohušová B, Hnát J, Gregor M, Delmia (2007) Tool of Digital factory. In: TRANSCOM 2007- $7^{\text {th }}$ European Conference of young research and science workers, EDIS-ŽU, Žilina. University of Zilina, Slovakia, p. 284.

6. Furmann R, Krajčovič M (2009) Interactive 3D Design of Production Systems. Digital Factory 2009-Workshop Handbook, Žilina, Slovakia. 
Your next submission with Juniper Publishers will reach you the below assets

- Quality Editorial service

- Swift Peer Review

- Reprints availability

- E-prints Service

- Manuscript Podcast for convenient understanding

- Global attainment for your research

- Manuscript accessibility in different formats

( Pdf, E-pub, Full Text, Audio)

- Unceasing customer service

Track the below URL for one-step submission https://juniperpublishers.com/online-submission.php 